INTERNATIONAL JOURNAL OF RESEARCHES IN BIOSCIENCES, AGRICULTURE AND TECHNOLOGY (c) VMS RESEARCH FOUNDATION

www.ijrbat.in

\title{
FISH BIODIVERSITY OF SAIKHEDA DAM WETLAND AREA OF LINGTI VILLAGE IN KELAPUR TALUKA, DIST.-YAVATMAL (M.S.), INDIA.
}

\author{
Sumedh K. Waware and R. R. Kamdi \\ Centre For Higher Learning And Research, Department Of Zoology, \\ Sardar Patel Mahavidyalaya, Chandrapur (Maharashtra) India. \\ Corresponding Author : kamdi.ramdas@gmail.com
}

Accepted : 24.01.19

Published: 30.01 .19

\begin{abstract}
:
The Saikheda dam Wetland area is situated in lingti village Taluka Kelapur of Yavatmal district in Maharashtra. Which is $20 \mathrm{~km}$ off Pandharkawada towards south east of Pandharakawada on Pandharakwada Yavatmal road this dam was constructed in 1972 on the river Khuni. This river Khuni originated near Mohada in Ghatanji taluka of Yavatmal district towards West north of the dam with located know. The Study area harbour's varying in shape. \& Size, in a rainy season a good habitat to various fish species. To assess the status and distribution of fishes, trips were conducted in the intensive study area. The fishes were classified based on their habitat and their presence was visually observed. A total of 19 fish species in upstream habitat. The status of fish fauna and management of Saikheda dam Wetland ecosystem has been discuss in this paper. Biodiversity is essential for balancing ecosystem and facing varied problems to environment. Globally nature as well as animal diversity are affected due to increase in unwise anthropogenic activities. Aquatic ecosystem is also adversely affected due to release of wastes in it. In the field of Ichthyology there is valuable contribution by many workers. As far as economic importance is concerned, the scope of fish and fisheries in Maharashtra is of prime interest. The current review deals with the freshwater fish recorded and confirmed by various species belonging to 07 orders, 09 families and 15 genera in Maharashtra during 2017 to 2018 and will be useful for fishermen, consumers, fish industry producers and researchers. Saikheda Project and Dam's Official Designation is "Saikheda , D -0 1247" . Saikheda Dam was constructed as part of irrigation projects by Government of Maharashtra in the year 1972. Nearest city to dam is Pandharkawada and the Dam is situated in Kelapur Taluka of Yavatmal District of Maharashtra. It is built on and impounds Khuni River. The dam is an Earth-fill Dam .Purpose of the dam is for irrigation.The length of dam is $1740 \mathrm{~m}$ ( 5708.66 Feet ), while the height of the dam above lowest foundation is 23.77 ( 77.98 Feet ). Detailed information about project spillway is not available. Project has a Spillway of Other type. Length of the spillway is not known. However measured length of the spillway is approximately $253 \mathrm{~m}$ (765 Feet). The Spillway is Ungated..Dam's catchment area is not known. Maximum / Gross storage capacity is $38.511 \mathrm{MCM}$. Live storage capacity is $27.184 \mathrm{MCM}$. Now days almost all the water bodies make for good picnic spots. Saikheda lake is also a popular Tourist attraction for its scenic beauty.
\end{abstract}

Keywords: Fish fauna, biodiversity, wetland and ecosystem.

\section{INTRODUCTION:}

Maharashtra is rich in freshwater (rivers, irrigation canals, dams, and lakes) reservoirs and its fish diversity. Therefore, Maharashtra is one of the important states for fish production and natural water resources and there is great scope for developing fisheries in this state. Fish diversity is declining rapidly each day due to unending anthropogenic stress. This diversity is not only the wealth of our world but it also has some serious implications on fishery. Thus there is an urgent need for proper investigation and documentation of this fish diversity in order to develop a fresh water fish diversity information system having both bioinformatics and georeferenced databases of fish and fish habitat. In the present review documentation of the fish fauna of fresh water reservoirs in the Maharashtra state for 2017 to 2018 is done.

Wetland ecosystem play a vital role in distribution of flora for aquatic, semi-aquatic and submerged floral association. The study of changed ecosystem is important for future planning which will help in conservation of natural flora, fauna and ecosystem for its future use and management when a natural ecosystem is destroyed obviously stability of system is also reduced. In Saikhada Wetland area large extent of tree were felled in catchment of this area is customarg to dress up the bare area contor trenched and afforested to pervert the reservior from silting up the flora on dam stream bank and afforestation on command areas of Wetland help in conservation of natural habitats. 
Normally, lakes perform the functions directly related to their physical, chemical and biological integrity to decide quality status of water. People on globe are under tremendous threat due to undesired changes in the physical, chemical and biological characteristics of air, water and soil. Due to increased human population, industrialization, use of fertilizers and manmade activity water is highly polluted with different harmful contaminants. Natural water contaminates due to weathering of rocks and leaching of soils, mining processing etc. It is necessary that the quality of drinking water should be checked at regular time interval, because due to use of contaminated drinking water, human population suffers from varied of water borne diseases. The availability of good quality water is an indispensable feature for preventing diseases and improving quality of life. Fishes occupy all three levels such as primary, secondary and tertiary consumer of food web in aquatic ecosystem. Man being the top carnivore in this food system as it is a very good source of protein. Fish protein is supposed to be cheapest. The production of million calories would take 15-20 mandays by fishing and 56 mandays by beef farming (Rath,2000). The investigations on the Indian fresh water fishes have mainly been restricted to taxonomy (Talwar and Jhingran 1991, Jayaram 1999).

The most characteristic criterion to assess the trophic structure of a lake remains to be primary productivity studies. The food chain in lake ecosystem is very simple comprising phytoplankton and aquatic vegetation as primary producers, zooplankton as primary consumers, small fishes as secondary consumers and large fishes as tertiary consumers.

Much of the current concern with regards to environmental quality is focused on water because of its importance in maintaining the human health and health of the ecosystem. Fresh water is finite resource, essential for agriculture, industry and even human existence, without fresh water of adequate quantity and quality, sustainable development will not be possible. There is an extensive literature, which stresses deterioration of fresh water fishes quality. The addition of various kinds of pollutants and nutrients through the agency sewage, industrial effluents, agricultural run off etc. in to the water bodies brings about a series of changes in the physicochemical and characteristics of water, which have been the subject of several investigations.

Fresh water resource is becoming day-by-day at the faster rate of deterioration of the fresh water fishes quality is now a global problem. Discharge of toxic chemicals, over pumping of aquifer and contamination of water bodies with substance that promote algae growth are some of the today's major cause for water quality degradation. Direct contamination of surface water with metals in discharges from mining, smelting and industrial manufacturing, is a long-standing phenomenon.

Today there is trace contamination not only of surface water but also of groundwater bodies, which are susceptible to leaching from waste dumps, mine tailings and industrial production sites. Organic manure, domestic waste and some fungicides often contain fairly high concentration of heavy metals. Soils receiving repeated applications of organic manures, fungicides and pesticides have exhibited high concentration of extractable heavy metals and that thereby increase their concentration in runoff (Moore et al., 1998), while falling as rain, water picks up small amounts of gases, ions, dust and particulate matter from the atmosphere. These added substances may be arbitrarily classified as biological, chemical (both organic and inorganic), physical and impurities. They include solvents, sediments, pesticides, herbicides, plant nutrients, decaying animal and vegetable matter and living microorganisms, such as algae, bacteria and viruses.

These impurities may give water a bad taste, colour, odour or turbidity and cause hardness, corrosiveness, staining or frothing. Water quality reflects the composition of water as affected by natural cause and man's cultural activities expressed in terms of measurable quantities and related to intended water use. The composition of surface and groundwater is dependent on natural factors (geological, topographical, meteorological, hydrological and biological) in the drainage basin and varies with seasonal difference in runoff volumes, weather conditions Groundwater is an increasingly important resource all over the world. The term 
groundwater is usually reserved for the subsurface water that occurs beneath the water table in soils and geologic formation that are fully saturated. It supports drinking water supply; livestock needs irrigation, industrial and many commercial activities.

Groundwater is generally less susceptible to contamination and pollution when compared to surface water bodies. The natural impurities in rainwater, which replenishes groundwater systems, get removed while infiltrating through soil strata. But, in India, where groundwater is used intensively for irrigation and industrial purposes, a variety of land and water based human activities are causing pollution of this precious resource. Importantly, groundwater can also be contaminated by naturally occurring sources.

Biological production in any aquatic body gives direct correlation with its physico-chemical status which can be used as trophic status and fisheries resources potential (Jhingran et al.,1969). Life in aquatic environment is largely governed by physico-chemical characteristics and their stability. These characteristics have enabled biota to develop many adaptations that improve sustained productivity and regulate lake metabolism. The most characteristic criterion to assess the trophic structure of a lake remains to be primary productivity studies.

The fresh water resources are very precious for the life on our planet. The number of dams, reservoirs, tanks, etc. has significantly increased in last few years. The aquatic ecosystem is important and it has large number of economically important animals especially fish which is an important source of food. The development of fisheries in these fresh water resources needs to be increased through the scientific development. Anthropogenic activities have drastically damaged the natural habitat of all the living beings.

Fresh water resources are used for various purposes, like agricultural, industrial, household, recreational, environmental activities etc. Though river water is used for agriculture, fisheries, residential and industrial developments, mining activity, navigation, power generation and variety of other activities including sand digging and disposal of industrial and domestic wastes, some natural breeding does exist in the nature. Identification of those natural breeding grounds and to bring them under proper conservation is the most effective way of natural breed conservation.

The reservoirs form one of the most important sources of large number of living aquatic animals, which are economically important for nature as well as for human beings as food. Cyprinid fish is one of the most important groups of vertebrates for man and influencing his life. The nutritive and medicinal value of fish has been recognized from ancient time to recent era.

Saikheda Project and Dam's Official Designation is "Saikheda , D -0 1247" . Saikheda Dam was constructed as part of irrigation projects by Government of Maharashtra in the year 1972. Nearest city to dam is Pandharkawada and the Dam is situated in Kelapur Taluka of Yavatmal District of Maharashtra . It is built on and impounds Khuni River ,. The dam is an Earthfill Dam .Purpose of the dam is for irrigation .The length of dam is $1740 \mathrm{~m}$ ( 5708.66 Feet ), while the height of the dam above lowest foundation is 23.77 ( 77.98 Feet ) . Detailed information about project spillway is not available. Project has a Spillway of Other type. Length of the spillway is not known. However measured length of the spillway is approximately $253 \mathrm{~m}$ ( 765 Feet )....... The Spillway is Ungated..Dam's catchment area is not known. Maximum / Gross storage capacity is 38.511 MCM. Live storage capacity is $27.184 \mathrm{MCM}$. Now a day almost all the water bodies make for good picnic spots. Saikheda lake is also a popular Tourist attraction for its scenic beauty. There are culture of fish with quick growing varieties of fishes including Indian Major Carps, exotic species have been popular in recent time. There is abundance of the species such as Labeo rohita, Cirrhina mrigal, Catla catla, Cyprinus carpio, Silver carp, Wallago atta, Mystacenbelus armatus, Notoptemus chital, Puntues ticto, Channa staitus, Mystus seenghala, Mystus cavaassius, Eutroplus suratensis, Belon concila, Chela, Tilapia Mossambica, Rohtee alfrediana, Gobius giuris, etc. Fish is economically a very important group of animals be side being used as food. Fish liver is an important source of oil containing Vitamins A and D, several minerals and protein. 
MATERIALS \& METHOD:

\section{Study area:}

Saikheda dam is situated at Yavatmal district in Maharashtra and its Geographical coordinates area 190268.53108" north 76040 43.71276" east. The Climatic condition of the area is generally dry. The Maximum and Minimum temperature recorded in the order of $47^{\circ} \mathrm{C}$ and $9^{\circ} \mathrm{C}$ in winter season. The Precipitation in these area mainly due to south west monsoon from June to October. The average annual rain fall in the order of $965 \mathrm{~mm}$. The area is classified as moderate zone under agroclimatic zone. The type of forest in these area generally tropical forest occupies most of the area in Maharashtra (Khanna, 1977). The major forest type of Yavatmal district is a typical tropical temperate forest. The work was carried out on seasonal basis from 2017 to 2018 . The sample where collected from different sampling station (s1, s2, s3, s4, s5) were collected.

\section{Fishes Analysis:}

For the study of ichthyofauna, fishes were collected with the help of local Government contractor and some local fishermen from the lakes and identified after (Day,1978; Jayram and Das, 2000; Jayaram and Sanyal, 2003; and Jayram, 1999,2010).

To investigate the Ichthyofaunal diversity of the Saikheda Dam freshly dead fishes were taken from fish markets for photographs and study purpose. The identification of the fish species was done on the basis of the colour pattern, specific spots/marks on body surface, body shape, structure of fins, mouth shapes etc. which are given in taxonomic key of Talwar and Jhingran (1991), Jayaram and Sanyal (2003). A study on Ichthyofaunal diversity of Saikheda Dam has been made in a year duration of June 2017 to May 2018.

\section{RESULT \& DISCUSSION:}

Result of the present study revealed the occurrence of 18 fish species belonging to 7 orders, 9 families and 15 genera were recorded from Saikheda Dam of Taluka Kelapur,Dist. Yavatmal (M.S.) India. Many workers are studied Taxonomy, biodiversity and distribution of fishes found in freshwater bodies of various parts of India.
Shinde S. E. et. al., (2009) was studied the freshwater fish biodiversity during period January 2008 to December 2008 to census and commercially important fishes in the Pravara River at Pravara Sangam Dist. Ahmednagar, Maharashtra, India. The result of present investigation showed that there were occurrence of 41 fish species belonging to 7 orders, 14 families and 26 genera. Jadhav B. V. et. al, (2011) were studied the freshwater fish fauna of Koyna River for a period of 2 years from May 2007 to April 2009. They were recorded 58 fish species belonging to 16 families and 35 genera. They were found that out of 58 fish species 8 endemic fish species are known to be threatened because of various anthropogenic activities.

Kharat S.S. et. al., were taken a survey of freshwater fish fauna of the Krishna river at Wai, and Dhom reservoir of stream of Wai. There were 51 fish species belonging to 14 families and 33 genera were recorded; 13 endemic to the Western Ghats and 2 to the Krishna river system. Similar results were found by Dr. Jayabhaye et. al, (2013) ichthyofaunal diversity of Pimpaldari tank in Hingoli district Maharashtra was found occurrence of 21 fish species belonging to 5 orders, 6 families and 13 genera. Sheikh S. R. (2014) was undertaken Ichthyofaunal studies during the period June 2011 to July 2013 on Pranhita River at Sironcha Dist. Gadchiroli. The result of present investigation revealed that occurrence of 37 fish species belonging to 21 different genera, in 11 families, 8 orders were recorded.

Likewise, Dhabe P. S. (2016) was studied that Morna River of Akola district had vast potential of fishery and supplied fishes to all over the district. During the year January 2015 to January 2016 she had reported that Morna river had diversity of fish fauna with 18 species belonging to 11 families out of which Channa punctatus, Channa striatus, Channa marulis, Wallago attu, Notopterus chitala, Mystes seenghala, Heteroneustes fossilis, Tilapia mossambica, Clarius batrachus, Mastacembelus pancalus and Pangasius pangasius are abundant.

CONCLUSION : 
Channa marulis was found most abundant. The family Belonidae was represented by one fish species Xenentodon cancila. The family Notopterus notopterus and the family Anguillidae was represented by Anguilla bengalensis bengalensis. The result of the present study revealed that Saikheda Dam being a freshwater resource supports a rich and diversified fish fauna. However, ichthyofaunal diversity of this dam is in declining mode due to several anthropogenic threats. In order to conserve these valuable resources, a holistic approach, integrating the concept of sustainable development and conservation measures should be adopted.

\section{REFERENCES:}

Dhabe P.S. (2016): Ichthyo-faunal diversity of Morna river basin, District Akola Maharashtra, India., Vidyabharti International Interdisciplinary Research Journal, pp. 196198.

Jadhav B.V., Kharat S.S., Raut R.N., Paingankar M., and Dahanukar N., (2011): Freshwater fish fauna of Koyna River, Northern Western Ghats, India. Journal of Threatened Taxa January 2011., 3 (1): pp 1449-1455.

Jayabhaye U.M., and Lahane L.D. (2013): Studies on Ichthyofaunal diversity of Pimpaldari tank, Hingoli, Maharashtra, India. International Indexed and Referred Research Journal, ISSN 0975-3486, (Print)E-ISSN-2320-5482, April-May (Combined), 2013 VOL-4 ISSUE 43-44 pp.54-55.

Jayaram K.C. and Sanyal A. (2003): A taxonomic revision of he fishes of the genus Mystus scopoli (Family: Begridae) Records of the Zoological survey of India occasional paper no. 207 ZSI Culcatta pp. 141.

J. Chandra Sekhara Rao G. Simhachalam \& CH. Sebastian Raju (2013): A study on
Ichthyofaunal diversity, conservation status and Anthropogenic stress of River Champavati, Vizianagaram District (AP) India. ASIAN J. EXP. BIOL. SCI. VOL 4(3), P. 418-425.

Kar, Kumar D. A., Bohra C., \& Singh L. K. (EDS) (2003), Fishes of Barak drainage, Mizoram and Tripura. In: Environment, Pollution and Management. Publishing corporation, New Delhi, 604: pp. 203-211.

Kharat S.S., Paingankar M., and Dahanukar N. (2012): Freshwater fish of Krishna River at Wai, northern Western Ghats, India. Journal of Threatened Taxa June 2012., 4 (6): pp 26442652.

Sheikh S. R. (2014): Studies on Ichthyofaunal diversity of Pranhita River, Sironcha, Dist. Gadchiroli, Maharashtra, India., International Journal of Fisheries and Aquatic Studies 2014; 1(5): pp. 144 - 147.

Shinde S. E. (2009): Fish Biodiversity of Pravara River at Pravara Sangam District Ahmednagar, (M.S.) India., World Journal of Zoology 20094 (3): pp. 176-179.

Talwar P.K and Jhingran A. (1991): Inland fishes of India and adjascent countries, Vol. 1 and 2, Oxford and IBH Publisher, New Delhi. pp. 1-158. 
Table No. 1 - Ichthyofaunal Diversity of Saiekhada Dam Wetland (During-2017-18):

\begin{tabular}{|c|c|c|c|c|}
\hline Sr. & Order & Family & Species & Common name \\
\hline \multirow[t]{8}{*}{1} & Cypriniformes & Cyprinidae & Catla catla & Catla \\
\hline & & & Labeo rohita & Rohu \\
\hline & & & Labeo bata & Tembti \\
\hline & & & Labeo boga & Chankora \\
\hline & & & Labeo pangsia & Boharya \\
\hline & & & Cyprinus carpio & Cyprinus \\
\hline & & & Puntitus dorsalis & Podshi \\
\hline & & & Puntitus chola & Tepri \\
\hline \multirow[t]{3}{*}{2} & Perciformes & Cichlidae & Tilapia mossambica & Talapia \\
\hline & & & Oreochromis & Kombada \\
\hline & & Gobidae & Glossogobinus giuris & Dhangarya \\
\hline \multirow[t]{3}{*}{3} & Synbranchiformes & Channidae & Channa marulis & Dokh \\
\hline & & & Chanda nama & Chandva \\
\hline & & Martacembelidae & Macrognathus pancalus & Bam \\
\hline \multirow[t]{2}{*}{4} & Siluriformes & Siluridae & Ompak bimaculatus & Patola \\
\hline & & & Mystus cavasius & Katirna \\
\hline 5 & Atheriniformes & Belonidae & Xenentodon cancila & Chatarya \\
\hline 6 & Osteoglossiformes & Notopteridae & Notopterus notopterus & Bhangad \\
\hline 7 & Anguilliformes & Anguillidae & $\begin{array}{c}\text { Anguilla bengalensis } \\
\text { bengalensis }\end{array}$ & Wire \\
\hline
\end{tabular}

